\title{
Physical and Morphometric Characteristics of Khillar Breed of Cattle
}

\author{
A.A. Adgale, B.S. Katkade*, S.B. Khade, M.M. Chopade and S.J. Komatwar \\ College of Veterinary and Animal Sciences, Parbhani- 431402, Maharashtra, India \\ *Corresponding author
}

\section{A B S T R A C T}

\begin{tabular}{|c|}
\hline Keywords \\
\hline $\begin{array}{l}\text { Physical and } \\
\text { morphometric } \\
\text { characteristics, } \\
\text { Cattle. }\end{array}$ \\
\hline Article Info \\
\hline $\begin{array}{l}\text { Accepted: } \\
\text { 04 July } 2017 \\
\text { Available Online: } \\
\text { 10 September } 2017\end{array}$ \\
\hline
\end{tabular}

The present study is on Physical and Morphometric characteristics of 248 (235 milking cows, 09 dry cows, 04 bulls) Khillar cattle breed at Bull Mother Farm, Junoni, Solapur. The Khillar cattle were compact and tight white skinned breed with significant variation among cows, bullocks and bulls and muzzle color was mostly black, mottled and carroty. Tail lengths were found to be for cows, bullocks and bulls of Khillar cattle were $111.29 \pm$ $0.77 \mathrm{~cm}, 119.45 \pm 0.43 \mathrm{~cm}$, and $114.08 \pm 1.05 \mathrm{~cm}$ respectively in straight shape. The shape of horns were typical curved with average length $55.85 \pm 0.22 \mathrm{~cm}$ in cows, $59.22 \pm 0.30$ $\mathrm{cm}$ in bullocks and $60.78 \pm 1.24 \mathrm{~cm}$ in bulls. Most of Khillar cattle were found in moderate temperament followed with tactile and docile temperament, breeding bull were wild temperament. The udders shape was mostly in round shape followed with bowl shape with medium to small size. The mean morphometric characteristics in cows, bullocks and bulls were found to be high in bulls followed with bullocks and cows. The correlations amongst different characters except slope of rump were highly significant indicating close relationship between them in males and females of Khillar cattle.

\section{Introduction}

India is the Agriculture dominated country in world. In India around 74.00 percent of our population lives in rural areas and depend on agricultural related enterprises, which are at mercy of mansoon. The mansoon is eratic in nature and create unemployment problem to rural people during dry span of year.

Livestock sector plays an important role in the welfare of India's rural population.

The cattle biodiversity in India constitutes 33 well-defined breeds of cattle apart from nondescript types and some lesser known breeds, which constitute around 75 per cent of the total cattle population.
There are 27 recognized breeds of Indian cattle of which four are milch purpose (Shiwal, Gir, Red Sindhi and Tharparkar), eight are dual purpose (Hariana, Ongole, Deoni, Kankrej, Nimari, Dangi, Mewati and Rathi) and fifteen are draught purpose. The draught breeds are Nagauri Rachaur, Malvi, Hallikar, Amritmahal, Bargur, Kangayam, Kenkatha, Kherigarh, Ponwar, Siri, Gaolao, Khillar and Krishna Valley. As per Joshi and Phillips (1953) Khillar cattle is classified as draught cattle breed of India. The breed owes its origin from Hallikar breed of cattle from Mysore state. There are four principle types known 1) Hanam Khillar or Atapadi Mahal prevalent in southern Maharashtra states of 
Bombay. 2) Mhaswad Khillar - Solapur and Satara district and adjoining areas of these districts. 3) Tapi Khillar or Thillar - In area of Satpura range of hills comprising the west Khandesh district like Jalgaon and Dhulia. 4) Nakali Khillar - In adjacent areas of these above regions.

Khillar is known for its various inherent qualities. Khillar excels in swiftness and more reliability due to light and compact body. This breed is pride of Maharashtra and its home tract is Marathwada and border districts of western Maharashtra districts. The typical Khillar animal is compact and tight skinned, with clean cut features. The whole appearance is like a compact cylinder with stout, strongly set limbs. There is a slight rise in the level of the back towards the pelvis. The ribs are well sprung and give the trunk a barrel shape. The hindquarters are squarely developed and the coup is well moulded. The gait of the Khillar is quick and spirited.

Khillar of the Deccan plateau, the Mhaswad and the Atpadi Mahal types are grayish white in colour. The color in the males is deeper over the forequarters and hindquarters, with peculiar gray and white mottles markings on the face. The Tapi Khillar is white with carroty nose and carroty hooves. The Nakali Khillar is gray with tawny or brick dust color over the forequarters. Today genetics is growing fast and world is also in need of evolution of such cattle breeds with maximum population to solve the agriculture problem. Very scanty work has been done on this breed.

\section{Materials and Methods}

\section{Physical characteristics}

The following data is on physical characteristics of 248 Khillar cattle maintained at Bull Mother Farm of Junoni, Dist. Solapur. They are as follow:

\section{Morphometric characteristics}

Total thirteen morphometric measurements were taken from all available Khillar cattle.

All the measurements were taken when animal were in a natural position on even surface. Arrangement has been made to stand the animal on even surface and in normal position at the time of measurement. The body measurements measured with the help of standard metallic tape.

\section{Analysis of data and methods used}

\section{Statistical norms}

The data were analyzed to calculate mean, standard deviation, standard error, percent coefficient of variation and correlations amongst different physical, morphometric characters as per standard statistical procedure.

\section{Percentage}

The percentage value for each observation was calculated as per following formula

$$
\text { Percentage }(\%)=\frac{\text { No. of observations in class }}{\text { Total no. of observations }}
$$

\section{Chi-square test $\left(\mathrm{X}^{2}\right)$}

Testing of homogenecity for various physical characteristics was tested by $m \quad x \quad n$ contingency as per Mukerjee and Banerjee (1980).

\section{Correlation coefficients and prediction equations}

The association between two characters, which can be directly observed, is the phenotypic correlation. The correlations 
amongst different physical and morphometric characteristics were calculated by the usual method of correlation analysis. Correlation coefficient (rxy) is given by:

$$
\begin{gathered}
(\Sigma \mathrm{X}) \mathrm{x}(\Sigma \mathrm{Y}) \\
\mathrm{n}
\end{gathered}
$$

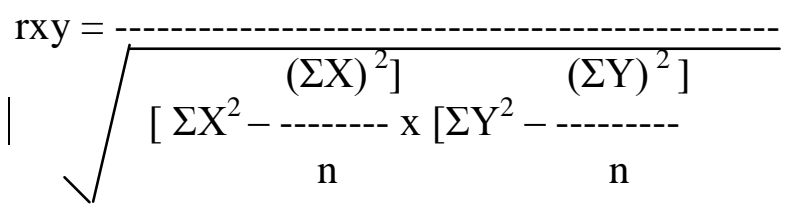

Where,

rxy $=$ correlation coefficient between $\mathrm{x}$ and $\mathrm{y}$ different variables

$\sum \mathrm{x} y=$ summation of products of $\mathrm{x}$ and $\mathrm{y}$ different variables in terms of various body measurements

$\sum \mathrm{x}=$ sum of $\mathrm{xi}$

$\sum y=$ sum of $y i$

$\sum \mathrm{x}^{2}=$ sum of square of $\mathrm{x}$ variables

$\sum y^{2}=$ sum of square of $y$ variables

$\mathrm{N}=$ number of observations per variable

$\Sigma=$ summation

\section{Standard error (SE) for correlation coefficients}

The standard error values for correlation coefficients were calculated as per the following formula

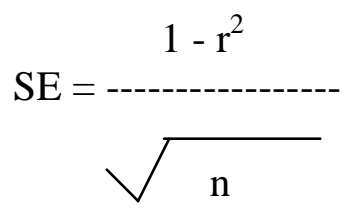

Where,

$\mathrm{SE}=$ standard error

$\mathrm{n}=$ number of total observations per variable

$\mathrm{r}=$ correlation coefficient

The ' $t$ ' values were calculated as per the given formula for test of significance

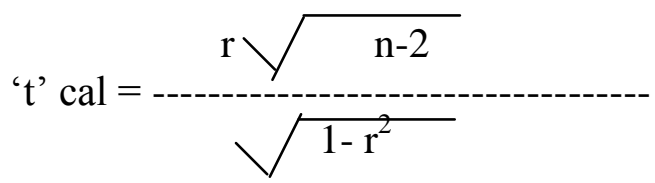

\section{Results and Discussion}

The characters studied include seventeen physical characters and thirteen morphometric characters. Among physical characters, coat colour observed in Khillar cattle were mostly white $(93.95 \%)$ followed by riddish $(3.63 \%)$ and blackish (9.84 \%) at CBF, COVAS, Udgir. Similarly at MAU, Parbhani farm clear white $(2.42 \%)$, with slight variation among male and female Khillar cattle. The muzzle colour found to be black (64.92\%), mottled $(20.16 \%)$ and carroty (14.91\%). The Chisquare $\left(\mathrm{x}^{2}\right)$ indicated non-significant variation among muzzle colour pattern of various male and female cattle.

The average horn length in cows, bullocks and bulls were found to be $55.85 \pm 0.22 \mathrm{~cm}$ in cows, $60.78 \pm 0.1 .24 \mathrm{~cm}$ in bullocks and $59.22 \pm 0.30 \mathrm{~cm}$ in bulls. The distance between two bases of horns in cows, bullocks and bulls were found to be $3.55 \pm 0.04 \mathrm{~cm}$, and $4.04 \pm 0.13 \mathrm{~cm}$ and $4.25 \pm 0.08 \mathrm{~cm}$ in cows, bullocks and bulls, respectively. The shape of horns of Khillar cattle was observed curved $(92.34 \%)$ and straight $(7.66 \%)$ in all Khillar breeds of cattle. The length of ears in cows, bullocks and bulls were found to be $26.37 \pm 0.07 \mathrm{~cm}$ for cows, $28.14 \pm 0.15 \mathrm{~cm}$ for bullocks and $23.75 \pm 0.42 \mathrm{~cm}$ for bulls. 
Ear orientations of Khillar cattle were found to be horizontal with non-significant variation in male and female. The basic temperaments of most Khillar cattle were moderate, docile, tactile and wild behaviors were 36.29 per cent, 20.16 per cent, 29.03 per cent and 14.51 percent respectively.

Udder shapes were mostly found to be round 51.91 per cent, followed by bowl shape udder 25.53 per cent, thorough 18.72 per cent and pendulus 3.83 per cent, respectively. The medium and small sizes of fore udder were found to be 75.74 per cent and 24.26 per cent, respectively. Similarly the medium and large sizes of rear udder were found to be 58.29 per cent, 41.71 per cent respectively. The teat shapes of all Khillar cattle were found to be cylindrical 63.40 per cent, funnel 24.68 per cent and pear 11.91 per cent. Therefore no significant variation found to be in teat shapes of Khillar breed of cows. In all Khillar cows, the teat tips were recorded as round teat tips 57.45 per cent and pointed 42.55 per cent. Also there were no significant variations for teat tips between lactating cows and dry cows of Khillar cattle. Teat lengths were measured for lactating and dry cows of Khillar cattle. The means of teat length along with SE 5.12 $\pm 0.46 \mathrm{~cm}$ for milking cows and $4.51 \pm 0.48$ $\mathrm{cm}$ for dry cows, respectively. The 't ' values for teat length of milking and dry cows of Khillar cattle were found to be significant indicating variation between teat length of milking and dry cows. Dewlap were found in medium size 92.74 per cent and large 7.26 per cent. The narrow size of chest was mostly found in Khillar breed of cattle, along with some Khillar cattle were found with wide size of chest.

Table.1 Physical Characteristics

\begin{tabular}{|l|l|l|}
\hline Sr. No. & Physical characteristics & Observation \\
\hline 01 & Coat color & White, Reddish and Blackish. \\
\hline 02 & Muzzle color & Black, Mottled and Carroty \\
\hline 03 & Tail shape & Black, Mottled and Carroty \\
\hline 04 & Tail length & From tail head to the end of switch of tail. \\
\hline 05 & Horn length & From base of horn to tip of horn. \\
\hline 06 & $\begin{array}{l}\text { Distance between two bases } \\
\text { of horns }\end{array}$ & $\begin{array}{l}\text { Measured in centimeter of the distance between two } \\
\text { bases of horns. }\end{array}$ \\
\hline 07 & Horn shape & Curved and straight \\
\hline 08 & Ear length & $\begin{array}{l}\text { Measured at lower surface of ear from junction to tip } \\
\text { of ear. }\end{array}$ \\
\hline 09 & Ear orientation & Horizontal or drooping. \\
\hline 10 & Basic temperament & docile, moderate, tactile or wild \\
\hline 11 & Udder shape & Bowl, round, through and pendulous shape of udder \\
\hline $\mathbf{1 2}$ & Fore udder & large, medium and small size \\
\hline $\mathbf{1 3}$ & Rear udder & large, medium and small size \\
\hline $\mathbf{1 4}$ & Teat shape & Before milking as cylindrical, funnel and pear shape. \\
\hline $\mathbf{1 5}$ & Teat tips & for pointed and round shape \\
\hline $\mathbf{1 6}$ & Teat length & $\begin{array}{l}\text { Measured from upper part of teat where it hangs } \\
\text { perpendicularly from the quarter at point where hair } \\
\text { growth has just started to the tip of the teat. }\end{array}$ \\
\hline $\mathbf{1 7}$ & Dewlap & Well develop, medium and small size \\
\hline $\mathbf{1 8}$ & Chest & Wide and narrow size. \\
\hline
\end{tabular}


Table.2 Morphometric characteristics

\begin{tabular}{|l|l|l|}
\hline Sr. No & $\begin{array}{l}\text { Morphometric } \\
\text { characteristics }\end{array}$ & Observation \\
\hline $\mathbf{0 1}$ & Body length & $\begin{array}{l}\text { Measured from point of shoulder to point of pin } \\
\text { bone of the same side. }\end{array}$ \\
\hline $\mathbf{0 2}$ & Length of face & $\begin{array}{l}\text { Measured from occipital crest to upper edge of } \\
\text { muzzle. }\end{array}$ \\
\hline $\mathbf{0 3}$ & Height at wither & $\begin{array}{l}\text { Measured from highest point over wither } \\
\text { immediately behind the hump to the ground }\end{array}$ \\
\hline $\mathbf{0 4}$ & Heart girth & $\begin{array}{l}\text { Distance of circumference around the barrel, } \\
\text { ventrally behind the elbow and dorsally behind the } \\
\text { point of wither. }\end{array}$ \\
\hline $\mathbf{0 5}$ & Paunch girth & $\begin{array}{l}\text { Largest circumference just in front of udder around } \\
\text { abdomen. }\end{array}$ \\
\hline $\mathbf{0 6}$ & Height at pin bone & Measured from pin bone to the ground \\
\hline $\mathbf{0 7}$ & Height at elbow & Measured from elbow joint to the ground \\
\hline $\mathbf{0 8}$ & Measurement below knee & Measured from knee joint to the ground \\
\hline $\mathbf{0 9}$ & Length from pin to hook & Measured from angle of hook bone to pin bone. \\
\hline $\mathbf{1 0}$ & Height at hook bone & From angle of hook bone to the ground. \\
\hline $\mathbf{1 1}$ & Width at hook bone & Between angles of hook bones. \\
\hline $\mathbf{1 2}$ & Height behind hump & Measured immediately behind hump to the ground. \\
\hline $\mathbf{1 3}$ & Slope of rump & $\begin{array}{l}\text { Measured by subtracting height at pin bone from } \\
\text { height at hook bone. }\end{array}$ \\
\hline
\end{tabular}

The mean tail lengths of cows, bullocks and bulls of Khillar cattle were $111.29 \pm 0.77 \mathrm{~cm}$, $119.45 \pm 0.43 \mathrm{~cm}$, and $114.08 \pm 1.05 \mathrm{~cm}$ respectively. The mean horn length in Khillar cattle $55.85 \pm 0.22 \mathrm{~cm}$ in cows, $59.22 \pm 0.30$ $\mathrm{cm}$ in bullocks and $60.78 \pm 1.24 \mathrm{~cm}$ in bulls. The mean distance between two bases of horns were found to be $3.55 \pm 0.04 \mathrm{~cm}, 4.25 \pm$ 0.08 and $4.04 \pm 0.13 \mathrm{~cm}$ in cows, bullocks and bulls, respectively. The mean ear length in Khillar cattle was found to $26.37 \pm 0.07 \mathrm{~cm}$ for cows, $23.75 \pm 0.42 \mathrm{~cm}$ for bullocks and $28.14 \pm 0.15 \mathrm{~cm}$ for bulls. In Khillar cattle morphometric characters studied in cows, bullocks and bulls.

The data was analysed to estimate the mean, standard error of various morphometric characters. The analysis also included the correlation amongst various morphometric characters. After analysis the means of various morphometric characters in $\mathrm{cm}$ in Khillar cattle for cows, bullocks and bulls were body length 137.34, 155.82 and 156.94; length of face 52.23, 56.12 and 58.20; height at wither 124.26, 138.10, 140.10; heart girth 163.62, 184.70, 186.35; paunch girth 181.40, 181.10 and 181.23; height at pin bone 119.27, 126.10 and 126.91; height at elbow 72.89, 79.00 and 78.72 ; measurement below the knee be 50.18, 54.27 and 53.82; length from pin to hook 44.48, 55.42 and 55.75; height at hook bone 136.26, 149.85 and 141.55; width at hook bone 27.74, 31.72 and 32.06; height behind hump 128.99, 150.32 and 150.95; slope of rump 16.98, 21.27 and 14.64, respectively.

The correlations mostly amongst various morphometric characters were significant except slope of rump. The slope of rump has shown non-significant correlation with other 
morphometric characters in male and female of Khillar cattle.

\section{Acknowledgment}

The authors are thankful to the Associate Dean, College of Veterinary and Animal Sciences, Parbhani, Maharashtra, India, for providing essential facilities to carry out this investigation.

\section{References}

Falconer, D.S., 1989. Introduction to Quantitative Genetics, $3^{\text {rd }}$ Edn. BLBL, Publication.

Gaikwad, B.B., P.G. Sakhare and K.S. Deshpande 1990. A note on body measurements of Red Kandhari breed of cattle. Indian Vet. J. 67(12): 1172.

Ghafoor, M.A., P.G. Sakhare and K.S. Deshpande 1980. Note on breed characterization of Red Kandhari cattle. Indian J. Anim. Sci. 50(8):652-654.

Giram, P.B., 2004. Breed characterization of Red Kandhari cattle in Osmanabad and Latur Districts of Marathwada region. M.V.Sc. thesis submitted to MAFSU University, Nagpur.

Joshi, N.R., R.W. Phillips 1953. Zebu cattle of India and Pakistan, FAO Agriculture studies No.19, Publ. by FAO, Rome, pp.256 Livestock census (2003) www.dahd.nic.in/relcensus.htm.

Mukerjee, D.P., and G.C. Banerjee 1980, Genetic and Breeding Farm Animal. Oxford and IDH. Publishing, Co. Pvt. Ltd. Kolkata.

\section{How to cite this article:}

Adgale, A.A., B.S. Katkade, S.B. Khade, M.M. Chopade and Komatwar, S.J. 2017. Physical and Morphometric Characteristics of Khillar Breed of Cattle. Int.J.Curr.Microbiol.App.Sci. 6(9): 513-518. doi: https://doi.org/10.20546/ijcmas.2017.609.061 